(C) Zachariou Z., 2016

UDC 616.712-007.24:616-089.23

DOI - http://dx.doi.org/10.14300/mnnc.2016.11022

ISSN - 2073-8137

\title{
PECTUS CARINATUM, OVERVIEW AND RESULTS OF ORTHOTIC BRACING THERAPY
}

Zachariou Z.

Medical School, University of Cyprus, Nicosia, Cyprus

КИАЕВИАНАЯ АЕФОРМАЦИЯ ГРУАНОЙ КАЕТКИ:
ОБЗОР И РЕЗУАЬТАТ ОРТОПЕАИЧЕСКОЙ КОМПРЕССИОННОЙ ТЕРАПИИ

3. Захариу

МеАицинская школа, Университет Кипра, Никосия, Кипр

\begin{abstract}
Pectus carinatum may occur alone or together with other congenital disorders or even syndromes, causing the sternum to protrude. Patients with pectus carinatum are generally asymptomatic however the deformity may induce lung and cardiac dysfunction. Pectus deformities can also have an impact on a child's self-image and self-confidence. In this paper we give an overview of the pathophysiology, the epidemiology, clinical presentation, diagnosis and differential diagnosis as well as treatment and management of this congenital condition and present our results applying orthotic bracing in 65 children including a survey from the patients and /or the parents. Our results are very promising with improvement of the quality of life for the patients and probably prevention of orthopedic problems such as scoliosis in the future.
\end{abstract}

Key words: pectus carinatum, orthotic brace, children

Килевидная деформация грудной клетки (КДГК) является самостоятельной нозологией или встречается в сочетании с другими врожденными нарушениями и синдромами. У пациентов с КДГК, как правило, заболевание протекает бессимптомно, однако могут отмечаться нарушения со стороны легких и сердца. КДГК также оказывает влияние на самооценку ребенка. В этой статье мы даем обзор патофизиологии, эпидемиологии, клинических проявлений, а также лечение и тактику ведения этого врожденного порока. В исследовании представлены результаты применения ортопедической компрессионной терапии у 65 детей, в том числе определение качества жизни пациентов и/или их родителей. Наши результаты являются весьма многообещающими, поскольку проведенное лечение улучшает качество жизни пациентов с КДГК и, возможно, обеспечивает профилактику ортопедических проблем, в том числе и сколиоза в будущем.

Ключевые слова: килевидная деформация грудной клетки, ортопедическая компрессионная терапия, дети

B ack as far as the $4^{\text {th }}$ century BC Hippocrates described this chest deformity as a "sharply pointed chest" in patients that demonstrated difficulty of breathing." The term pectus carinatum or keel shaped breast or pigeon breast is used to describe a spectrum of protrusion abnormalities of the anterior chest wall. Although many affected patients have no or little complaints most of the patients especially adolescents indicate concerns about body image with low self-esteem and subsequently a decreased quality of life [1]. These cosmetic concerns have to be considered significant factors for correction of this congenital malformation.

Pectus carinatum deformity was thought to be asymptomatic until recently. However new studies have proven that cardiopulmonary function can be impaired throughout the life of these children. Some patients develop a rigid chest wall, in which the AP diameter is almost fixed in full inspiration making respiratory efforts less efficient. Vital capacity can be reduced whereas residual air is increased resulting in alveolar hypoventilation with arterial hypoxemia and the development of cor pulmonale. The lungs lose compliance, incidence of emphysema and frequency of infection are increased.

The overall prevalence of pectus carinatum in the United States is estimated at $0.06 \%$ [2] whereas in Brazil
[3] and Argentina [4] the percentage is greater. This condition is more frequent in whites and is uncommon in blacks and Asians. Heredity is shown at least in $25 \%$ of the patients [5]. A male predominance is obvious with males being affected 4 times more frequently than females. Pectus carinatum can also be seen in association with Marfan syndrome and congenital heart disease.

Although etiology has not been established till now, the increased incidence of positive family history and associated anomalies suggests an abnormality in connective tissue development [6] and abnormal overgrowth of the rib cage during development of the chest wall. Most patients are asymptomatic and symptomatic patients report exertional dyspnea, tachypnea as well as decreased endurance and musculoskeletal chest pain and tenderness, especially when lying in the prone position [7].

Psychological and cosmetic concerns are the most prominent reasons for initial consultation, most frequently in mid childhood worsening during the adolescent growth spurt. Morbidity in later years includes cardiac and hemodynamic changes.

The aim of our study was to investigate efficiency of orthotic bracing therapy in children with pectus carinatum.

Material and Methods. Between 2007 and 2014 we treated 65 children ( 22 girls and 43 boys) with orthotic 
bracing for pectus carinatum applying the method described above. The mean age was 13.2 years and the treatment duration for each child was 12 months whilst the mean follow-up was 4.5 years. The protocol included the first consultation followed by the measurements for the brace in a specialized orthopedic company. The brace was adapted by the doctor for the first time and the patients or the parents were instructed how to apply the brace (Fig.1). In case the fitting was not correct the patient was sent back to the firm for re-fitting, the mean corrections for all braces was 2. 14 days later another consultation took place and we evaluated with the patient any problems. In case everything was correct the patient was flowed-up every 2 months until the first 6 months were over. Then the patient came for a consultation in 6 months where the result was evaluated.

We developed a questionnaire with 10 questions regarding the convenience of the brace therapy as well as compliance and complications.
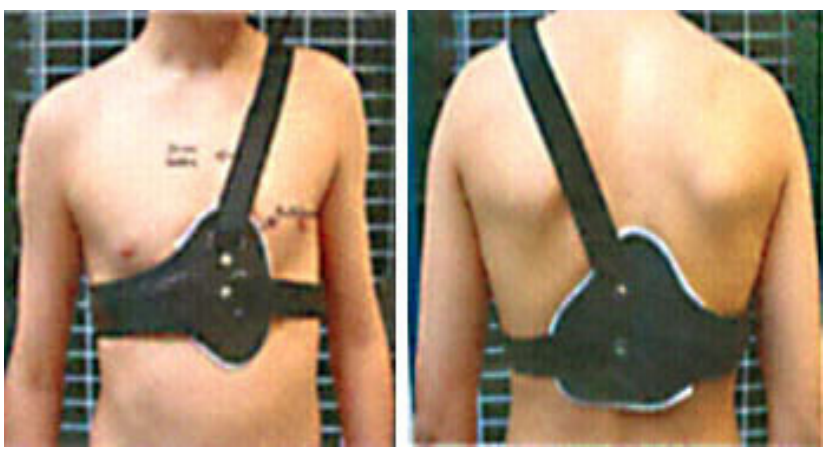

Fig. 1. The application of the orthotic brace

Results and Discussion. Orthotic bracing with the correct compression results in a significant improvement in the appearance of the patients especially in early age. There was an improvement in exertional symptoms and endurance in all symptomatic patients after completion of the one year treatment. However, patient compliance and diligent follow-up appear to be paramount for the success of this method of treatment. The survey, see below reviled very good results and there was no recurrence of pectus carinatum in patients who underwent the treatment for the follow-up period of a mean of 4.5 years (Fig. 2). Minimal recurrence of pectus carinatum occurred in 4 patients who stopped wearing the compressive brace after 6 months.
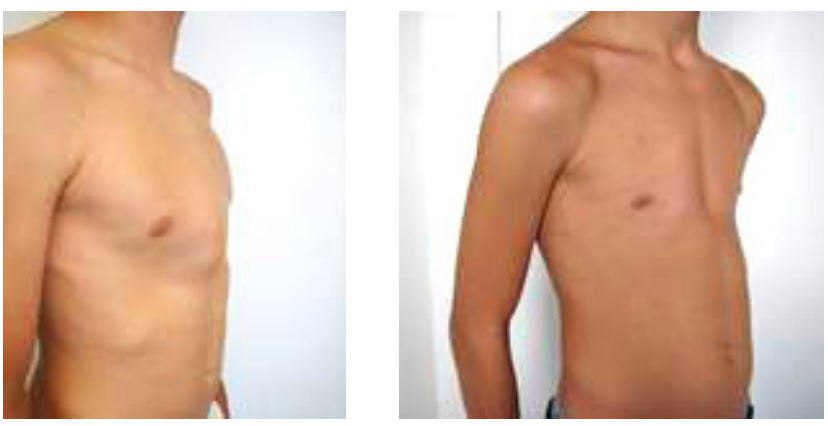

Fig. 2. Patient before and after application of the orthotic brace

The response was $95.4 \%$ as 62 out of 65 children or parents answered. The results were excellent as $86.1 \%$ of the parents reported that they would repeat the treatment and $78.5 \%$ of the children also. At Figure 3 reflects the percentages of treatment satisfaction on a scale of 1 (low) -5 (very good).

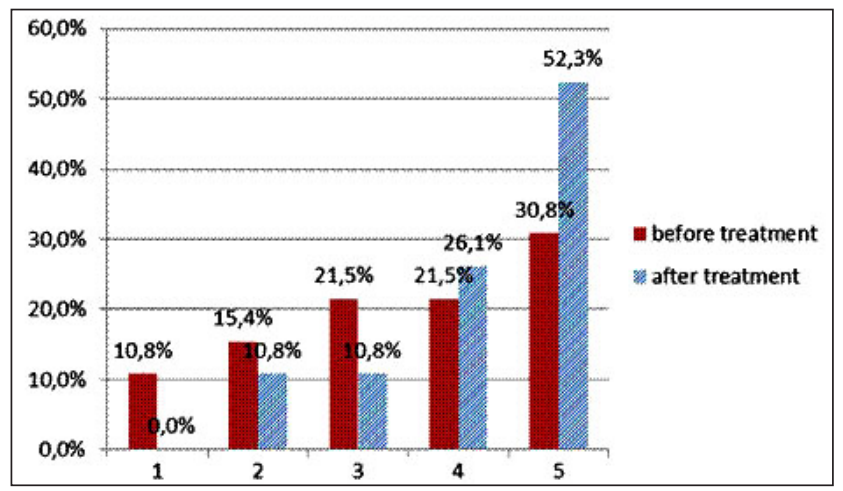

Fig. 3. Subjective suffering of children and their parents before and after treatment

Pectus carinatum is a clinical diagnosis based on the physical inspection of the chest. In the majority of cases it occurs as an isolated anomaly or in association with congenital heart disease or with another skeletal anomaly (20\% scoliosis).

Posteroanterior and lateral Radiographic imaging should be performed. Additional imaging with either a chest CT scan or MRI may also be helpful [8].

Pulmonary function studies may be tailored to address concerns about clinical symptoms and the appearance of the chest wall upon examination. Exercise testing may complement these studies [9].

Electrocardiography and echocardiography may be considered if congenital heart disease is suspected whereas mitral valve prolapse as well as decreased myocardial contractility may be observed.

In cases of additional dysmorphic signs, chromosomal analysis and metabolic testing may be considered.

The first line therapy for pectus carinatum, especially in patients younger than 18 years with malleable chest walls is the orthotic bracing $[10,11]$. The long-term success rates are $65-80 \%$ which are very encouraging [7].

The therapy involves a self-adjustable, low-profile bracing system applied in 2 phases. The initial phase involves $24 \mathrm{~h} / \mathrm{d}$ bracing for 6 months followed by the second phase, as a maintenance phase, during which the brace is worn only at night [12]. This is an effective treatment under the condition that the patients and parents compliance is high. It eliminates the risks of surgery and anesthesia and does not preclude surgery if unsuccessful.

Surgical therapy may be the initial consideration in older patients with more rigid chest walls. Various methods have been described however since the number of surgically treated patients has decreased dramatically we refer to the literature for further details: Fonkalsrud (2008) [5], de Matos (1997) [13], Shamberger (1987) [14], Del Frari (2011) [15], and Cohee (2013) [16]

However as many corrections are performed for cosmetic reasons, decreasing the size of incisions is important and reports were made using an endoscopic approach [15].

Individuals with pectus carinatum who have significant concerns about their body image or low self-esteem may benefit of psychological counseling

III-fitting braces can be associated with skin irritation and skin breakdown. Surgical complications may include pneumothorax $(2.6 \%)$, wound infection $(0.7 \%)$, atelectasis $(0.7 \%)$, and local tissue necrosis $(0.7 \%)$ with an overall complication rate of $4 \%$ [14].

In prepubertal children with pectus carinatum who are compliant with bracing, success rates are excellent (up to $80 \%$ ).

Excellent results $(97.4 \%)$ have been reported by Fonkalsrud (2008) in patients who underwent surgical correction using a very limited resection of deformed 
cartilage and immediate chest stabilization [5]. In addition, he reported less postoperative pain, shorter hospital stays, lower complication rate, and decreased cost. Furthermore, he reported satisfactory cosmetic results with the less extensive repair, as well as a high rate of improvement in exertional symptoms compared with more extensive open surgical procedures. Recurrences are rare.

Responses to quality-of-life questionnaires in patients who had undergone minimally invasive repair of their pectus deformity supported a positive impact on psychosocial function [17].

\section{References}

1. Steinmann C., Krille S., Mueller A., Weber P., Reingruber B. Pectus excavatum and pectus carinatum patients suffer from lower quality of life and impaired body image: a control group comparison of psychological characteristics prior to surgical correction. Eur $J$ Cardiothorac Surg. 2011;40(5):1138-1145.

2. Mielke C. H., Winter R. B. Pectus carinatum successfully treated with bracing. A case report. Int Orthop. 1993;17(6):350-352.

3. Martinez-Ferro M., Fraire C., Bernard S. Dynamic compression system for the correction of pectus carinatum. Semin Pediatr Surg. 2008;17(3):194-200.

4. Obermeyer R. J., Goretsky M. J. Chest wall deformities in pediatric surgery. Surg Clin North Am. 2012;92(3):669684 , ix.

5. Fonkalsrud E.W. Surgical correction of pectus carinatum: lessons learned from 260 patients. J Pediatr Surg. 2008;43(7):1235-1243.

6. Heithaus J. L., Davenport S., Twyman K. A., Torti E. E., Batanian J. R. An intragenic deletion of the gene MNAT1 in a family with pectus deformities. Am J Med Genet $A$. 2014;164A(5):1293-1297.

7. Calloway E. H., Chhotani A. N., Lee Y. Z., Phillips J. D. Three-dimensional computed tomography for evaluation and management of children with complex chest wall anomalies: useful information or just pretty pictures? $J$ Pediatr Surg. 2011;46(4):640-647.

8. Castile R. G., Staats B. A., Westbrook P. R. Symptomatic pectus deformities of the chest. Am Rev Respir Dis. 1982; 126(3):564-658.
Conclutions. Symptoms that were reported for these patients included dyspnea, exertional tachypnea, and reduced endurance as well as low self-esteem making the therapy important for the personality development of these children. Over time, the trend towards less surgical techniques has resulted in low morbidity, mild pain, short hospital stay and very good physiologic and cosmetic results. Therefore, according to our results we currently offer this approach as a first-line treatment for pectus carinatum.

9. Frey A. S., Garcia V. F., Brown R. L. et al. Nonoperative management of pectus carinatum. I Pediatr Surg. 2006;41(1):40-45.

10. Lee R. T., Moorman S., Schneider M., Sigalet D. L. Bracing is an effective therapy for pectus carinatum: interim results. J Pediatr Surg. 2013;48(1):184-190.

11. Wong K. E., Gorton G. E. 3rd, Tashjian D. B., Tirabassi M. V., Moriarty K. P. Evaluation of the treatment of pectus carinatum with compressive orthotic bracing using three dimensional body scans. J Pediatr Surg. 2014;49 (6):924-927.

12. Kobayashi S., Yoza S., Komuro Y., Sakai Y., Ohmori K. Correction of pectus excavatum and pectus carinatum assisted by the endoscope. Plast Reconstr Surg. 1997;99(4):1037-1045

13. de Matos A. C., Bernardo J. E., Fernandes L. E., Antunes M. J. Surgery of chest wall deformities. Eur $J$ Cardiothorac Surg. 1997;12(3):345-350.

14. Shamberger R. C., Welch K. J. Surgical correction of pectus carinatum. J Pediatr Surg. 1987;22(1):48-53.

15. Del Frari B., Schwabegger A. H. Ten-year experience with the muscle split technique, bioabsorbable plates, and postoperative bracing for correction of pectus carinatum: the Innsbruck protocol. J Thorac Cardiovasc Surg. 2011;141(6):1403-1409.

16. Cohee A. S., Lin J. R., Frantz F. W., Kelly R. E. Staged management of pectus carinatum. I Pediatr Surg. 2013;48(2):315-320.

17. Cano I., Anton-Pacheco J. L., Garcia A., Rothenberg S. Video-assisted thoracoscopic lobectomy in infants. Eur J Cardiothorac Surg. 2006;29(6):997-1000.

About author:

Zachariou Zacharias, MD, PhD, Professor, Pediatric Surgeon, Medical School of University of Cyprus;

tel.: +35799273371; e-mail: zachariou.a.zacharias@ucy.ac.cy

(C) Group of authors, 2016

UDC 616.348-002-053.2

DOI - http://dx.doi.org/10.14300/mnnc.2016.11023

ISSN - 2073-8137

\title{
FAST TRACK IN THE TREATMENT OF NEWBORNS WITH NECROTIZING ENTEROCOLITES
}

Minaev S. V. ${ }^{1}$, Obedin A. N. ${ }^{1}$, Kachanov A. V. ${ }^{1}$, Annenkov M. V. ${ }^{2}$, Tovkan E. A.2', Gerasimenko'I. N.'

1 Stavropol State Medical University, Russian Federation

2 Regional Children's Clinical Hospital, Stavropol, Russian Federation

\section{УСКОРЕННАЯ РЕАБИАИТАЦИЯ В АЕЧЕНИИ НОВОРОЖАЕННЫХ С НЕКРОТИЧЕСКИМ ЭНТЕРОКОАИТОМ}

\author{
С. В. Минаев ${ }^{1}$, А. Н. Обелин ${ }^{1}$, А. В. Качанов ${ }^{1}$, М. В. Анненков ${ }^{2}$ \\ Е. А. Товкань ${ }^{2}$, И. Н. Герасименко
}

1 Ставропольский госуаарственный меАицинский университет, Российская ФеАерация 2 Краевая Аетская кАиническая больница, Ставрополь, Российская Фелерация

In the article consider the actual problem of fast track in newborns with NEC. Patients were divided into two groups matched for gestational age, weight and sex of patients. The Group1 consisted of 18 infants with NEC stage 2 to 3 , in which the complex treatment was provided using presacral blockade with ropivacaine. The Group 2 was 